\title{
İlhanlılar İdaresinde Şîrâz (684/1286-735/1335)
}

\author{
Akif Rençber*
}

\section{Öz}

Şîâzzşehri, Moğol yıkımından az bir hasarla kurtuldu. Buna rağmen hem merkezden uzak olması hem de farklı güç odaklarının varlı̆̆ı Şîrâz’’ her zaman idaresi zor bir şehir yaptı. Bu bağlamda İlhanlı şahnesi, ikta sahipleri ve baskaklar şehirde çok başlı bir idareyi kaçınılmaz kılıyorlardı. Üstelik şahne sayısı bazen üç kişiye kadar çıabiliyordu. Bu sebeple Şîrâz'da İlhanlılar lehine sükûnet ortamı hiçbir zaman tam olarak sağlanamadı. Şîrâz'da İlhanlılar dönemini (684/1286-735/1335) üç kısma ayırmak mümkündür. Birincisi; 684/1286-692/1293 yılları arası Salgurlu bakiyelerinin kısa sürelerde değiştiği ve İlhanlı şahnesi ile müştereken Şîrâz'1 yönettikleri dönemdir. İkinci dönem; 692/1293-725/1325 yılları arasında Melikü’lİslam Cemaleddin ve onun oğlu İbrahim'in İncu arazilerinin geliri karşıllı̆ı̆ında Şirâz'da bir nevi dihkan mevkiinde olduğu dönemdir. Bu arada ikinci dönem ve üçüncü dönem arasında (718/1319-730/1330) Şîrâz'da İlhanlı soyundan gelme Salgurlu bakiyeleri ile bizzat İlhanlı hükümdarlarının birinci derece akrabaları İncu gelirlerinde pay sahibi olmuştur. Ancak kısa sürelerde bu pay sahipleri değişmiştir. Üçüncü dönem; 725/1325-735/1335 yılları arasında İlhanlı merkezi otoritesinin zayıflamasına paralel olarak Şîẫz'ın İnculular tarafından büyük oranda bağımsız yönetildiği dönemdir. Bu çalışma, son Salgurlu idarecisi Abiş Hatun'un 1286'da İlhanlılar tarafından görevden el çektirilmesinden, son İlhanlı hükümdarı Ebu Said Bahadır Han'ın vefatına kadar geçen süreçte (735/1335) Şîrâz şehrinin siyasî tarihini konu almaktadır.

Anahtar Kelimeler: Şîrâz, İlhanlılar, Salgurlular, Şeyh Cemaleddin, İnculular

\footnotetext{
* Dr. Serbest Araştırmac1, ORCID: /0000-0002-1758-6250, akifrencber@hotmail.com
} 


\title{
Shiraz Administration of Ilkhanids (684/1286-735/1335)
}

\author{
Akif Rençber*
}

\begin{abstract}
City of Shiraz escaped damage of Mongol Invasion with a little destruction. Nevertheless it was difficult to manage Shiraz because of both being away from the center and the existence of different power groups. In this regard, a multiheade administrtation was inevitable with the Shahneh of Ilkhanids, landowners and Baskaks. Moreover, sometimes there might be up to three shahneh. For this reason, the stationary tranquility (state) was never fully established in favour of the Ilkhanids in Shiraz. In Shiraz, Ilkhands reign (1286-1335) can be reviewed in three periods. (terms) In the first period (684/1286-692/1293), Salgurid remnants was changing in short terms and managing the city of Shiraz with Shahneh of Ilkhanids jointly. Second period was the term between 692/1293-725/1325 in which Melikü'l Islam Cemaleddin and his son were at sort of dihkan position in exchange for revenues of Inju lands. Meanwhile, between the years 718/1319$730 / 1330$, Salgurid remnants which are descandents of Ilkhanids and immediate relatives of Ilkhanid Dynasts were allottees of revenues of Inju lands. However this ownership had changed in short terms. In the third period $(725 / 1325-735 / 735)$, Injuids had dominated the city of Shiraz to a large extend, corresponding to Ilkhanid central auhority became weaker. This study is about the period in political history of Shiraz between last Salgurid administrator Abis Hatun who was discharged by Ilkhanids in 684/1286 and the death of Ebu Sad Bahadir Khan in 735/1335 who is the last Ilkhanid Emperor.
\end{abstract}

Keywords: Shiraz, Ilkhanids, Salgurids, Seyh Cemaleddin, Injuids

Phd. Independent Researcher, ORCID: /0000-0002-1758-6250 akifrencber@hotmail. com 


\section{Giriş}

İran'da tarihi bir şehir olan Şîrâz, Fars idare merkezinin tam ortasında yer almaktadır. Şehir, bugünkü İran topraklarının güneyinde 29 derece ve 38 dakika kuzey enlemi, 52 derece ve 40 dakika doğu boylamında yer alır. ${ }^{1}$ Kadim bir geçmişe sahip olan şehir, Sâsânîlerden sonra ilk İslam fetihleriyle beraber Müslümanların kontrolüne geçti. Şîrâz, Emevîler ve Abbasilerden sonra Saffârîlerin hâkimiyetine girdi. Bundan sonra 322/934'den itibaren uzunca bir süre Büveyhîlerin idaresinde kaldı. Hatta Büveyhîler Şîrâz'ı idare merkezi yaparak hatırı sayılır imar faaliyetinde bulundular. Selçuklular devletlerini kurduktan kısa bir süre sonra başladıkları fetih hareketleriyle Şîrâz'a kadar ulaştılar. Ancak tam anlamıyla Fars ve Şîrâz'a egemen olmaları Melik Kavurd döneminde 453/1062 yılında gerçekleşti. Melik Kavurd'un saltanat mücadelesi sonucu ölümü üzerine Fars ve Şîrâz'da Selçuklular adına Emirler ve Atabeyler yönetici olarak görev yapmaya başladılar. Zaman içinde Salgurluların hem idare hem de askeri yönetimde etkinliğinin artması sonucu Fars hâkimi Melikşah'ın atabeyi Sungur, kardeşinin öldürülmesini bahane ederek isyan etti. Melikşah'1 Şîrâz'dan çıkartarak yönetimi uhdesine aldı (543/1148-1149). ${ }^{2}$

Salgurlular, 543/1148'den itibaren Şîrâz ve çevresinde meşruluk kaynaklarını yine Selçuklulardan almak kaydıyla hâkim olmuşlardır. Selçukluların yıkılmasından sonra kısa bir süre Harzemşahlıların hâkimiyetini tanıyan Salgurlular, daha sonra Moğol/İlhanlı egemenliğini tanıdılar. Buna rağmen Şîrâz ${ }^{3}$ ve çevresinde varlıklarını 684/1286 yılına kadar sürdürdüler. ${ }^{4}$

1 Kerametullah Efser, Tarih-i Baft-ı Kadim-i Şîrâz, (Tahran: İntişarat-1 Encomin-i Asar ve Mefahir-i Ferhengi, 1374), 34; Osman Gazi Özgüdenli, "Şîrâz", Türkiye Diyanet Vakfi İslam Ansiklopedisi, c. 39, (İstanbul: TDV Yay., 2010), 182.

2 Zerkûb Şîrâzî, Şîrâzname, tsh. İsmail Vaiz Cevadî, (Tahran: İntişarat-1 Bünyad-1 Ferheng-i İran, 1350) 43-52; Erdoğan Merçil, Salgurlular, (Ankara: TTK Yayınları, 1991), 2-35.

3 Bu arada Şîrâz, bu vahşet asrının İran'ında en mamur şehirlerden biri haline geldi. Zira âlimler, şairler ve diğer ilim sanat erbabları için bir sığınma merkezi olan şehir, ileri gelenlerin adeta yarışırcasına yaptırdığı imaretlerle zamanının ilerisinde bir kültür ve ilim hayatı yaşadı. Salgurlu hanedanının erkeklerinin yanı sıra kadınları da bu hususta oldukça cömert idiler. (Şîrâzî, Şîrâzname, 85; Abdü'l-Muhammed Ayetî, Tahrir-i Tarih-i Vassaf, (Tahran: İntişarat-1 Bünyad-1 Ferheng-i İran, 1346), 91-108; Reşîdüddin Fazlullah, Câmiu't-Tevârih -İlhanlılar Klsml-, çev. İsmail Aka, Mehmet Ersan, Ahmad Hesamipour Khelejani, (Ankara TTK Yayınlar1, 2013), 51; İbnü'lEsir, el-Kâmil fi 't-Tarih Tercümesi, c. X, çev. Ahmet Ağırakça vd. (İstanbul: Hikmet Neşriyat, 2008), 328-329; Minhâc-1 Sirâc el-Cûzcânî, Tabakât-ı Nâsırî, çev. Erkan Göksu, (Tokat: Taşhan Kitap Yayınları, 2011), 87; Bertold Spuler, Iran Moğolları, çev. Cemal Köprülü, (Ankara: TTK Yayınları, 2011), 352.

4 Erdoğan Merçil, "Salgurlular", Türkiye Diyanet Vakfi İslam Ansiklopedisi, c. 36, (Ankara: TDV Yay., 2009), 30. 
1220 yıllarında başlayan Moğol istilasına Şîrâz merkezli Fars bölgesi hâkimi Salgurlular da dâhil oldu. Bu bağlamda Moğollar 629/1231-1232 yılında Ahlat'ta iken civar hükümdarlar Moğol otağına elçiler göndererek itaatlerini sundular. Salgurlu hükümdarı Atabek Ebu Bekir b. Sa'd (12261260), Moğolların huzuruna elçi yollayarak haraç vermeyi kabul etti. Böylece Şîrâz'da Moğollara tabii bir yönetim başladı. Öğeday (Oktay) Han döneminde gerçekleşen bu olay ile Atabek Ebu Bekir, Moğollara 30.000 dinar vermekle beraber Moğol şahnesini müştereken yönetime kabul etmişti. Atabek Ebu Bekir, Moğolların Şîrâz ve diğer Fars bölgesi yerleşimlerini yağmalamalarının önüne geçmek için bu boyunduruğu kabul etmek zorundayd1. Ancak kendince önlemler almaktan geri durmadı. Buna göre Moğol şahnesini Şîrâz'a sokmayarak onlara şehrin dışında özel bir konaklama merkezi tahsis etti. ${ }^{5}$

Atabek Ebubekir'in vefatından Abiş Hatun'un İlhanlı gelini olmasına kadar geçen süreçte, Salgurlu tahtına sırasıyla II. Sad b. Ebubekir, Atabek Muhammed (Naibi Terken Hatun), Salgurşah oğlu Muhammed Şah, Selçukşah ve Abiş Hatun geçtiler. Ancak bu süreçte İlhanlılar merkezden atadıkları valiler vasıtasıyla varlıklarını doğrudan hissettirtiyorlardı. Buna paralel Salgurlular ise güçten düşmekteydi. 662/1264'de Selçukşah öldükten sonra tahtın tek varisi olan Abiş Hatun Salgurlu hükümdarı oldu. Ancak onun varlığ bu dönemde sembolik olmaktan öteye geçemedi. Zira İlhanlı valisi Altacu mutlak hâkim idi. Bu arada mehdi olduğuna inandıkları Seyyid Şerefüddin İbrahim'in etrafinda toplanan Şîrâz halkı İlhanlılara isyan ettiler. Bu isyan Altacu tarafindan bastırıldı. Altacu'dan sonra Ankiyanu ve Soğuncak Şîrâz' da görev yaptılar. ${ }^{6}$

Şîâyz'da müstakil bir idarecinin olmaması nedeniyle 667/1268/1269 y1lında Abaka'nın emriyle Ankiyanu (آنكيانو) atand1. Akabinde 670/1271 y1lında Şîrâz'a atanan Soğuncak (سوغونجاق) Noyan görevini tamamlayarak 671/1272 yılında Mengü Timur'un nişanlısı Abiş Hatun'la beraber Şîrâz'a geri döndü. Onun ayrılmasından sonra Şîrâz'da yerel idareciler birbirleriyle çatışma içinde oldular. Yaşanan karmaşadan dolayı Abaka Han,

5 Şîrâzî, Şî̀âzname, 85; Ayetî, Tahrir-i Tarih-i Vassaf, 91-108; Erdoğan Merçil, Salgurlular, s. 86.

6 Ayetî, Tahrir-i Tarih-i Vassaf, 96-114; Bahriye Üçok, İslam Devletlerinde Türk Naibeler ve Kadın Hükümdarlar, (İstanbul: Bilge Kültür Sanat Yayınları, 2011), 162163. 
678/1279'da Soğuncak Noyan'1 bir kez daha idari ve mali işlerin tanzimi için Şîrâz'a yolladı. 681/1282 yılında ise Mengü Timur'un ölümünden sonra İlhanlı hükümdarı Ahmet Teküder, Abiş Hatun'u Şîrâz'a idareci olarak yolladi. ${ }^{7}$

Bu çalışma, son Salgurlu idarecisi Abiş Hatun'un 1286'da İlhanlılar tarafindan görevden el çektirilmesinden, son İlhanlı hükümdarı Ebu Said Bahadır Han'ın vefatına kadar geçen süreçte (735/1335) Şîrâz şehrinin siyasî tarihini konu almaktadır.

\section{Salgurlu İdaresinin Sonu, Şîrâz'da İlhanlı Hâkimiyetinin Başlaması}

Moğol gelini olan Atabek Abiş, Salgurlu saltanatının son temsilcisi olarak Ahmet Teküder'in izniyle Şîrâz'a geldi ve idareyi uhdesine aldı. Onun gelişi sonrası Şîrâz'da sükûnet sağlanmasına rağmen kısa süre sonra şehirde iktidar kavgası ortaya çıktı. Zira sabık Şîrâz yöneticilerinden Seyyid İmadüddin şehri terk ederek İlhan'ın huzuruna gitmişti. Bu olaylar yaşanırken İlhanlı merkezinde taht değişikliği gerçekleşmiş, yeni hükümdar Argun Han'ın huzuruna çıkan Seyyid İmadüddin, aldığı Yarlıg ile Şîrâz yönetimini uhdesine almıştı. Bu gelişmeler sonrası Atabek Abiş taraftarları ve Seyyidler arasında yaşanan çekişme İmadüddin'in öldürülmesiyle sonuçlanınca Atabek Abiş İlhanlı merkezi tarafindan azledildi. ${ }^{8}$

Şîrâz ileri gelenleri Abiş'in azledilmesinden sonra uzun bir süre rakiplerini saf dışı bırakmak için İlhanlı merkezinde kaldılar. Bununla beraber bir çığ yumağına dönüşmüş sorunların çözümü ve birikmiş olan borçların silinmesi için uğraş verdiler. Şîrâz hâkimleri Fars'ın kendilerine verilmesi halinde İlhan'a 500 tümen ödemeyi taahhüt ederek eyaletin yönetimini almayı başardılar. Argun Han, onlara bu izni vermekle beraber tahsilatın düzenli bir şekilde yapılabilmesi ve olası muhalefetin engellenebilmesi için

7 Ayetî, Tahrir-i Tarih-i Vassaf, 112-123.

8 Ayetî, Tahrir-i Tarih-i Vassaf, 124-130; Üçok, İslam Devletlerinde Türk Naibeler ve Kadın Hükümdarlar, 166; (Abiş'in vasiyeti gereği şahsına ait olan emlak çocukları arasında pay edildi. Aynı zamanda Seyyid'in öldürülesinden dolayı suçlanan Abiş'in, onun mirasçılarına 50 tümen (500.000 dinar) ödemesine hükmedildi. Abiş azledilip İlhanlı merkezine geldikten bir yıl dört ay sonra hastalandı. Kısa bir süre sonra ise vefat etti. Onun saltanatı iki yıl iki ay sürmüştür. (Ayetî, Tahrir-i Tarih-i Vassaf, 130.) 
Fahreddin Mübarekşah'1 "Bitikçi" unvanıyla görevlendirildi. İlhan'dan Yarlıg alan bu heyetin lideri Kıvamüddin Buharî, Fars'a yakın bir yere gelindiğinde vefat edince Hace Şemseddin Hüseyin, Seyfeddin Yusuf ve Nizameddin Ebubekir Şîrâz'a ulaşarak bir takım atamalar gerçekleştirdiler. Ancak İlhan'a ödemeyi vaat ettikleri miktar oldukça yüksek bir meblağ olduğu için bu konuda müşkül durumda kaldılar. ${ }^{10}$

Şîrâz için artık çalkantılı bir dönem başlıyordu. Bu dönemde sıkça şehir ileri gelenlerinin İlhanlı hükümdarının huzuruna varmak suretiyle çeşitli imtiyazlar elde etmeye çalıştığını görmekteyiz. Hükümdarın huzuruna çıkan ileri gelenler sundukları muhtelif hediyelerle makam elde etmeye çalışıyorlardı. Otağda kaldıkları süre zarfında rakiplerine karşı savunmasız olanlar ise onların gammazlamasıyla bertaraf edilip muradına ermeden cezalandırılıyorlardı. İmtiyaz elde edenler ise bunu kötüye kullanarak mütemadiyen süren yönetici değiş̧ikliğine ek olarak istikrarsız bir siyasi atmosferin meydana gelmesine neden oluyorlard1. 684/1286'dan 692/1293 y1lına kadar Şîrâz'da yönetici değişikliğinin sıkça yaşanması artık sıradan bir durum haline gelmişti. ${ }^{11}$

Abiş Hatun'un Şîrâz'dan ayrılmasından sonra onun idarecilerinden olan Celaleddin Arkan derhal öldürüldü. Diğer Salgurlu idarecileri; Vezir Hace Nizameddin, Hace Seyfeddin Yusuf ve Fahreddin Mübarekşah hapsedildi. Kısa bir süre sonra merkezden atanan İlhanlı yöneticisi Cuşi (عشوج) tarafindan kılıçtan geçirildiler. ${ }^{12}$ Bu gelişmeler ile Şîrâz'da Salgurlu idaresi son bulurken, Moğollar yeni bir düzenlemenin ilk adımlarını atıyordu. Bununla beraber 686/1288-688/1290 yıları arasında Şîrâz'da Salgurlu idarecilerinden Mecidüddin Rumî, görev yaptı. Bütün idarecilerin üstünde yetkiye sahip olan Mecidüddin Rumî, görev süresi boyunca birçok hayrat yaptırd1. Yaptırdığı hayratlara ait kitabe Şîrâz'ın Istahr kapısı üzerine nakşedilmiştir. ${ }^{13}$

Şîây' da Salgurlular sonrası Moğol hâkimiyetinin başlarında ve sonrasın-

9 Bitikçi (بيتكى ) İlhanlılarda bir çeşit maliye memuruna verilen isim. (Muhammed Muin, Ferheng-i Farsî, c. 1, (Tahran: Müessese-i İntişarat-i Emir Kebir, 1388), 618.)

10 Ayetî, Tahrir-i Tarih-i Vassaf, 131; John Limbert, Shiraz in the Age of Hafez, (Seattle \& London: Universty of Washington Press, 2004), 22.

11 Limbert, Shiraz in the Age of Hafez, 23-24.

12 Reşî̀düddin Fazlullah, Câmiu't-Tevârih, 168; Ayetî, Tahrir-i Tarih-i Vassaf, 132.

13 Şîrâzî, Şîrâzname, 96-97. 
da şehir ileri gelenleri iki hizip arasında seçim yapmak zorunda kalmış gibi görünmektedir. Bu hiziplerden biri Atabek Abiş'e karşı duygusal bir bağ hissedenlerden oluşurken, diğerleri ise Şîrâz'daki yeni yönetime meyl edenleri ihtiva eder. Ancak Abiş taraftarları sınırlı bir güce sahipti. ${ }^{14}$

\section{3. Şeyh Cemaleddin Dönemi ve Gazan Han'ın Reformları Bağlamında Şiraz}

688/1290 y1lı sonlarında Mecidüddin Rumî öldürülünce Şemsüddevle, Şîrâz'ın idaresini 691/1292 yılına kadar uhdesine aldı. Argun Han vefat edince yerine geçen Geyhatu'nun tasarrufu gereği Şîrâz' da yönetici değişikliği oldu. Zira Şîrâz, 684/1286 y1lında son Salgurlu hanedan mensubu Abiş Hatun'un görevden el çektirilmesiyle doğrudan Moğol idaresine geçmişti. Buna rağmen yerel bir idare mekanizması zorunluluk arz etmekteydi. Bu sebeple oluşan otorite boşluğu, başlangıçta Salgurlu bakiyesi idareciler vasitasıyla doldurulmaya çalışıldı. Ancak bu durum isabetli olmayınca Şîrâz yöneticiliği şeyh olarak nitelendirilen Cemaleddin'e verildi. 692/1293 y1lı başlarından 725/1325 yılına kadar İlhanlılara ait topraklar, mukataa olarak otuz yılı aşkın bir süre Melikü'l-İslam Cemaleddin ve onun oğlunun uhdesinde kaldı. Cemaleddin, Geyhatu'ya ödediği 10.000.000 dinar ile dört yıllığına Fars'da ekilebilir İncu arazilerinden ${ }^{15}$ vergi toplama imtiyazını elde etti. Cemaleddin, başka hiçbir Moğol soylusunun müdahalesi olmaksızın tek başına böyle bir imtiyazı elde etmişti. Ancak onun elde ettiği bu imtiyaz çok uzun süreli olmadı. ${ }^{16}$

14 Limbert, Shiraz in the Age of Hafez, 22.

15 İncu kelimesi İlhanlılarda hükümdarın ve ailesinin özel emlakı ile buralarda yaşayan esir ve kulları ifade etmek için kullanılmıştır. İncu Arazileri, İran soylularından el konularak elde edilen ve Moğol fetihleri sonrasında İlhanlı ailesi mensuplarına verilen arazilerden oluşmaktaydı. Yani mahalli hanedanlara ait topraklar bu kategoride değerlendirilmiştir. Bu arada çeşitli sebeplerle sahipsiz kalan topraklar ve satın alma yoluyla elde edilenlerle beraber zaman içinde İncu topraklarının miktarında artış olmuştur. Bu arazilerden elde edilen kaynak oldukça büyüktü. Buna göre; Argun Han zamanında bu arazilerden elde edilen gelir 600.000 dinar, Gazan Han zamanında ise 1.000.000 dinara tekabül etmekteydi. (I. P. Petrushevsky, "The Socio-Economic Condition of İran Under The İlkhans", The Cambridge History of İan, vol. 5, (Cambridge University Press, 1968), 516; Osman Gazi Özgüdenli, "İncu”, Türkiye Diyanet Vakfi Íslam Ansiklopedisi, c. 22, (İstanbul: TDV Yay., 2000), 281.)

16 Şîrâzî, Şîrâzname, 96-99; Limbert, Shiraz in the Age of Hafez, 24; Osman Gazi Özgüdenli, Gazan Han ve Reformlarl, (İstanbul: Kaknüs Yayınları, 2009), 185; I. P. Petrushevsky, "The Socio-Economic Condition of İran Under The İlkhans", 516. 
Şîrâz'ın Cemaleddin'e tevdi edilmesinde güdülen gaye; Muhtemelen şeyhin nüfuzundan istifade ederek halk ve ileri gelenler ile İlhanlı yönetimi arasında iletişimi sağlamaktı. Şîrâz'da Seyyid nüfusunu dikkate alırsak nüfuz sahibi ve itibarlı bir kişilik olarak Seyyidlere hitap edecek şeyhlik mertebesinde bir şahsın İlhanlılar adına Şîrâz'da arzu edilen bir yönetim ortaya koyması kuvvetle muhtemeldir.

İlhanlılar ile Şîâzzlı yerel idareciler arasında ilişkiler daimi surette sorunlu oldu. Gazan Han, tahta ilk çıtığı sıralarda İlhanlı ülkesine tam anlamıyla hâkim değildi. Bilhassa mali konularda yani merkeze vergi verme hususunda bir başkaldırı söz konusuydu. Bu konuda Fars eyaletinin ön plana çıktığını görmekteyiz. Baydu ile girdiği taht mücadelesinde İlhanlı tahtına ortak olan Gazan, yapılan antlaşma gereği 694/1294-1295 yılında içinde Şîrâz'ın da bulunduğu bir miktar toprağı kendi idaresine aldı. Bu bağlamda aynı yıl içinde 100 tümenlik vergi tahsili için Şîrâz'a memurlar gönderildi. Ancak Gazan'ın gönderdiği memurlar Cemaleddin tarafindan eli boş gönderildiği gibi hakarete maruz bırakıldı. Bu sebeple Gazan, tahta çıktığında Fars ve Şîrâz idarecilerine karşı fazla müsamahakâr davranmadı. ${ }^{17}$

Gazan Han, İlhanlı tahtına çıktıktan sonra 695/1296 yılında Fars eyaletinin vergi tahsildarı olarak Emir Hûrkûdâk'1 görevlendirdi. Onun Şîrâz'a gelişiyle İlhanlılar adına idare daha sağlam bir zemine oturdu. ${ }^{18}$ Gönderdiği ferman ile Cemaleddin'in huzura gelmesini istedi. Cemaleddin muhtemelen geçmişte yaptıklarından dolayı Şîrâz hâkimiyetini kaybetme endişesi ile karşı karşıya olduğunun farkındaydı. Bu sebeple Gazan Han'ın huzuruna hazırlıklı çıktı. Değerli ve eşi benzeri olmayan hediyeler ile amacına ulaşarak tekrar iki yıllığına Şîrâz'da İncu toprakların idaresini almayı başardı. Bununla beraber rakibi İzzüddin Muzaffer'i saf dışı bırakarak olası bir riski de ortadan kaldırd. ${ }^{19}$

$\mathrm{Bu}$ arada Cemaleddin, Kiş’in muhafazası için Bahaeddin Ayaz ile girdiği

17 Şîrâzî, Şîrâzname, 99; Ayetî, Tahrir-i Tarih-i Vassaf, 202; Özgüdenli, Gazan Han ve Reformlarl, 186.

18 Ayetî, Tahrir-i Tarih-i Vassaf, 202.

19 Reşîdüddin Fazlullah, Câmiu't-Tevârih, 262; Özgüdenli, Gazan Han ve Reformlart, 186; Cemaleddin, Kiş'in muhafazası için Şîrâz'dan uzak olduğu sırada İzzeddin Muzaffer, onun aleyhinde bir takım girişimde bulundu. Hurkudak işin aslını öğrenmek maksadıyla yaptığı tahkikat sonucunda Cemaleddin' in herhangi bir suça bulaşmadığını öğrenince İzzeddin Muzaffer, Şîrâz'dan uzaklaştırıldı. (Ayetî, Tahrir-i Tarih-i Vassaf, 202.) 
deniz savaşı sonrası devlet hazinesine büyük miktarda ganimet kazand1rarak Şîrâz'a geri dönünce İlhanlılar nezdinde itibarı daha da arttı. Zira o sırada Şîrâz'da bulunan İlhanlı elçileri duruma bizzat şahit olmuştu. ${ }^{20}$

698/1298-1299 yılında on altı kısma ayrılan Şîrâz ve çevresinin vergi gelirleri üç y1l için 1000 tümen olarak belirlenmişti. Bu verginin tahsili yap1lırken halka karşı kötü muamelenin önüne geçmek için Gazan Han, özel bir görevli dahi tayin etmiştir. Bu bağlamda Melik Muazzam Şerefüddin Simnânî görevlendirilmiştir. Ancak Gazan Han'ın aldığı tüm önlemlere rağmen Şîrâz'da yaşanan kıtlık, kuraklık ve veba salgınına ek olarak tahsildarların halktan fazla vergi toplaması felaketin boyutlarının daha da arttırdı. Aynı tarihte Şîrâz ve çevresinde vebadan takriben 90 bin kişi yaşamını yitirdi. ${ }^{21}$

Öte yandan Spuler' in işaret ettiğine göre; 660/1262'den beri faaliyet sahas1 bilhassa Fars olan baskaklar, ${ }^{22}$ Şîrâz'da yönetici olarak görev yapmıştı. Bu zaman dilimi, Atabek Abiş Hatun'un hanedan mensubu Mengü Timur ile evlenerek Şîrâz'in idaresini doğrudan Moğollara terk ettiği döneme denk gelmektedir. Baskaklar 694/1295 yılına kadar etkin bir şekilde (Daha doğrusu Gazan Han'ın toprak reformu yapmasına kadar.) Şîrâz merkezli Fars bölgesinde bu vazifelerini icra etmişlerdir. Onların görevi sadece vergi toplamak değil aynı zamanda bulundukları yeri korumaktı. Bu bağlamda Lur saldırısında Şîrâz'1 korumuşlardı. ${ }^{23}$

Gazan Han döneminde hayata geçirilen yenilikler çerçevesinde toprakların işlenmesini sağlayarak askere doğrudan para vermek yerine arazi vererek mali yükü hafifletmek için toprak reformu yapıldı. ${ }^{24} \mathrm{Bu}$ uygulama özellikle

20 Ayetî, Tahrir-i Tarih-i Vassaf, 202.

21 Ayetî, Tahrir-i Tarih-i Vassaf, 210-219; Özgüdenli, Gazan Han ve Reformları, 186187.

22 Baskak (باسقاق) İlhanlılarda mahalli vergi memurlarına verilen isim. ( Muin, Ferheng-i Farsî ,c. 1, 458. )

23 Spuler, İran Moğolları, 353.

24 Boş ve metruk araziler tarıma açılarak hazineye yeni gelirler elde edildi. Bunun için hem halk hem de devlet ileri gelenleri teşvik edilerek bir miktar vergi karşıllı̆ında topraklar tarıma açıldı. Bu dönemde sulanabilen-mamur, yarı harap durumda olan ve tamamen harap olan araziler şeklide topraklar üç kısma ayrıldı. Bu arazilerden alınacak vergiler de birbirinden farklı olacaktı. Vergiler aşamalı bir şekilde dördüncü yılın sonunda tam olarak tahsil edilebilecekti. Bu arazilerin defter kayıtları ve teftişi için de ayrıca düzenlemeler yapılmıştı. (Özgüdenli, Gazan Han ve Reformları, 301302.) 
Fars bölgesinde hayata geçirildi. Bununla Baskakların sebep olduğu Şîrâz ve civar yerleşimlerde yaşanan yolsuzlukların önüne geçmek istenmekteydi. Baskaklar yönetimden el çektirilerek Şîrâz merkezli tüm Fars bölgesinde daha düzenli ve sistematik bir idare ortaya çıkarılacaktı. Ancak baskaklar arkalarında büyük bir enkaz bırakmışlardı. Bu sebeple Gazan Han'ın buyruğu gereği üç senelik vergi muafiyeti uygulandı. Ancak askerlerin tarım hakkındaki bilgilerinin sınırlı olmasına ek olarak merkezden teftiş için gelen memurların yolsuzluk ve rüşvet noktasında ısrarlı tavırları üzerine bu uygulamadan bir süre sonra vazgeçildi. ${ }^{25}$ Bununla beraber reformlar sayesinde Şîrâz' 'n gelirlerinde 500 bin dinarlık bir artış gerçekleşti. ${ }^{26}$

Öte yandan Çağataylıların Şîrâz'a yaptığı yağma seferlerinin ortaya çıkardığı endişe nedeniyle Gazan Han döneminde Şîrâzlıların isteği doğrultusunda şehrin surları 702/1303'de onarıldı. Masrafı ise hazineden karş1land1. ${ }^{27}$ Gazan Han döneminde yapılan reformlardan bir başkası zekâtın ülke genelinde belirlenen oran nispetinde toplanmasıydı. Bu bağlamda 701 (1301-1302) yılında ülke genelinde toplanması kararlaştırılan 200 bin dinarlık kısmın 40 bin dinarı Şîrâz’’n hissesine düşmekteydi. ${ }^{28}$ Bütün İlhanlı ülkesi düşünüldügünde Şîrâz'ın payına düşen kısmın oldukça yüksek bir meblağa tekabül ettiği görülmektedir. Bu bilgi tek başına Şîrâz'ın oldukça zengin olduğunu göstermektedir.

Gazan Han döneminde eşkıyalara karşı yolların güvenliği sağlamak için bir takım görevliler (râhdârân) tayin edilmekteydi. Bu bağlamda Şerefüddin Muhammed Muzaffer, Şîrâz ve Kirman'ın emniyetinden sorumlu kişi olarak tayin edildi. ${ }^{29}$

$\mathrm{Bu}$ arada Gazan Han döneminde merkez eyaletlerin imar ve bayındırlık hizmetlerinden oldukça fazla istifade ettiğini, buna karşılık merkezden uzak olan Şîrâz'ın bundan nasibini yeterince alamadığını belirtmek gere-

25 Spuler, İran Moğolları, 353.

26 Özgüdenli, Gazan Han ve Reformları, 301.

27 Ayetî, Tahrir-i Tarih-i Vassaf, 231; Özgüdenli, Gazan Han ve Reformlarl, 306; Hasan Pîrniya ve Abbas İkbal Aștiyanî, Tarih-i İran ez Â̆gaz ta İnkıraz-ı Silsile-i Kacariyye, (Tahran: Neşriyat-1 Heyyam, 1380), 522.

28 Ayetî, Tahrir-i Tarih-i Vassaf, 233-234; Özgüdenli, Gazan Han ve Reformlarl, 337.

29 Özgüdenli, Gazan Han ve Reformları, 343; C. E. Bosworth, Doğuşundan Günümüze Íslam Devletleri Tarihi, çev. Hande Canlı, (İstanbul: Kaknüs Yayınları, 2005), 347; Bu kişi, 1353 yılında Şîrâz'ın idaresini uhdelerine alan Muzafferilerin atası olarak bilinir. 
kir. ${ }^{30} \mathrm{Bu}$ durum sadece imar faaliyetlerinde yaşanmıyordu. Aynı zamanda idari ve mali yönetime de olumsuz bir şekilde yansımaktaydı. Zira merkezden uzak olunması İlhanlı yöneticilerinin ve yerel idarecilerinin idareyi kötüye kullanmasını, idarecilerin yolsuzluk ve rüşvet gibi bir takım gayrimeşru işlere meyletmesini kolaylaştırmaktaydı. Zaman zaman İlhanlı idarecileri yerel yöneticilerle işbirliği yaparak onların usulsüzlüklerine ortak olmaktaydı. Bundan başka merkezin izni dışından yükledikleri vergilerle kişisel servet yapabilmekteydiler. Bu gibi durumlar Şîrâz'da idarî, malî ve sosyal düzenin istikrarsız seyretmesine neden olmaktayd.

Öte yandan İlhanlılar döneminde Fars eyaletinde Şî̂ nüfus diğer bölgelere nazaran fazla olmamakla beraber bir miktar bulunmaktaydı. Bölgenin en önemli şehri olan Şîrâz'da Şafiiler ve Şiîler birlikte yaşamaktaydı. Şîrâz geçmişte olduğu gibi İlhanlı idaresinde de Sâsânî geleneklerinin varlığını devam ettirdiği bir şehir olarak bilinir. Şehirde bulunan Seyyidler, Büveyhîlerin devamı olarak kendilerini görmektedir. Bu sebeple kendilerinden olmayan yönetimleri benimsememişlerdir. ${ }^{31}$ Bu bağlamda Şîrâz'da bulunan Seyyid nüfusunun yaşanan bazı gelişmelerden rahatsızlık duyduğunu görmekteyiz. Bu dönemde Kadı İzzeddin Alevi Kad'ül-Kudat'lık vazifesinden azledilerek bütün malı müsadere edilmişti. Bu olaya seyirci kalmayan Seyyid taraftarları Şîrâz'da kalabalık, servet sahibi ve güçlü olduklarını bahane ederek Kadı İzzeddin'in görevine geri dönmesini ve mallarının geri iadesini talep ettiler. Aksi takdirde ayaklanarak Şîrâz' da bağımsız bir idare kuracakları tehdidinden bulundular. Ancak onların tehdidi bir sonuca ulaşmad1. ${ }^{32} \mathrm{Bu}$ durum ister istemez yerel idareciler ile İlhanlı merkezinden atananlar arasında bir çatışma sebebi olmuştur. Merkezden uzak olması nedeniyle Şîrâz'ın idaresinde yaşanan aksaklıklara bir de yerel hassasiyetlere vakıf olmayan idareciler eklenince Şîrâz'da istikrarlı bir yönetim sağlanamamıştır.

30 Ayetî, Tahrir-i Tarih-i Vassaf, 261; Özgüdenli, Gazan Han ve Reformlarl, 172.

31 Şîrîn Beyânî, Din-u Devlet Der Iran Ahd-ı Moğol, c. 2, (Tahran: Merkez-i Neşr-i Danişgahi, 1371), 624-625; Hamdullah Müstevfî, Nüzhetü'l-Kulub, çev. Guy Le Strange, (Leiden 1919), 113; Hanifi Şahin, İlhanlılar Döneminde Şiîlik, (İstanbul: Ötüken Yayınları, 2010), 199.

32 Ayetî, Tahrir-i Tarih-i Vassaf, 96; anlaşıldığı kadarıyla Şîrâz'da hatırı sayılır bir miktarda Hz. Ali taraftarları bulunmaktadır. Bu dönemde onlara Alevi denilmekle beraber onlar Seyyid olarak da bilinmektedirler. 
Olcaytu tahta çıktığında Şîrâz'da İlhanlılar adına yerel idareci olarak Cemaleddin bulunuyordu. ${ }^{33}$ 704/1304 y1lında yani Gazan Han'ın vefatından bir yıl sonra Şîrâz'da Cemaleddin'e karşı huzursuzluk ve muhalefet baş göstermeye başladı. Daha önce merkezi otorite ve Şîrâz arasında yaşanan idarî ve malî krize ek olarak sorunların devam etmesi nedeniyle Olcaytu, merkezden atadığ yöneticiler ile ortak bir şekilde üç yıl süreyle onun Şîrâz'da idaresine müsaade etti. 706 yılında Cemaleddin'in ölümüyle Şîrâz idaresi oğulları el-Fazl Şemseddin ve Melik İzzeddin'in eline geçti. Melik İzzeddin, Şîrâz'da kalıcı olmayı hedeflediğinden Olcaytu'ya muhalefet etmeden sırtını ona dayayarak siyaset güttü. Bu sebeple rakipleri arasında ön plana çıkmayı başardı. Sadece Şîrâz'ın değil tüm Fars eyaletinin idaresini uhdesine ald. Bununla beraber İlhanlı merkezinden atanan Emir Sadık, baskak olarak yedi yıl süreyle Şîrâz'da görev yaptı. Şîrâz'da Emir Sadık’tan sonra Emir Âştû (آشتو) şahne oldu. Melik İzzeddin ile Âştû Şîrâz'ın idaresi konusunda problem yaşadıkları için Melik İzzeddin onun azledilmesi yönünde Olcaytu nezdinde sürekli girişimlerde bulundu. Çabalarının sonucu olarak Emir Âştû'nun azledilmesini sağlayan Melik İzzeddin, böylece tek başına Şîrâz'ın idaresini eline aldı. Fakat Emir Âştû işin peşini bırakmayarak bir miktar süvariyle Şîrâz'a yöneldi. 10 Zilkâde 716/24 Ocak 1317 tarihinde şehre ulaştı. Öte yandan Melik İzzeddin, Âştû karşısında tutunamayacağını anlayınca çareyi kaçmakta buldu. Âştû, Şîrâz yönetimini eline geçirerek şehirdeki muhalif tüm unsurları uzaklaştırdı. Tüm bunlara rağmen onun Şîrâz egemenliği kısa sürdü. Melik İzzeddin tekrar Şîrâz’ı ele geçirdi. ${ }^{34}$

714/1314-1315 yılında Hace İzzeddin Kuhdî ( قو هدى ) Şîrâz'da düzen sağlamak üzere görevlendirildi. Onunla beraber aynı zamanda Melik-i Azam Şeyh Behlül, müştereken Şîrâz'a gönderilmişti. Bir süre dervişlik yaparak sufîler ile teşrik-i mesaide bulunan Şeyh Behlül, Şîrâzname müellifinin belirtiğine göre iş bilir ve çalışkan birisiydi. Bu ikilinin şehirde göreve başla-

33 Olcaytu'nun hükümdarlı̆̆ı döneminde Fars bölgesinde Şîrâz merkezli hâkimiyet, Melik İzzeddin Abdülaziz b. Cemaleddin İbrahim'in elindeydi. O merkezi otoriteye isyan edince, Olcaytu, onu bertaraf etmek için Fars Şahnesi Âştû'yu görevlendirdi. $\mathrm{Bu}$ ordu ile başa çıkamayacağını bilen Cemaleddin İbrahim, Fars'ın sahil kesimlerine firar etti. (Ebu'l-Kasım Abdullah b. Muhammed el-Kâşânî, Tarih-i Olcaytu, (Tahran: İntişarat-1 İlmi ve Ferhengî, 1384), 154.)

Şîrâzî, Şîrâzname, 99. 
masından sonra Şîrâz'da huzur ortamı kısa süreliğine sağlandı. ${ }^{35}$ Şîrâz'da tasavvuf ehli ya da şeyh mertebesindeki kişilerin görev aldığı zaman halk1 ve ileri gelenleri İlhanlı merkezi otoritesine karşı ehil bir hale getirdiğini görmekteyiz. Bu durum şehrin dini karakterini ortaya koyması bakımından önemlidir.

Olcaytu'nun Şiîliği tercih ettiği tarihten itibaren Şiîlerin İlhanlı merkezinde ve taşrasında yavaş yavaş etkinliklerini arttırdıklarını söylemek gerekir. ${ }^{36}$ Şîrâz'da mevcut Şiî nüfusun varlı̆̆g gereği Seyyidlerin en azından kendilerini daha özgürce ifade etmelerine imkân bulduklarını ifade edebiliriz. Öte yandan Olcaytu, Şiîliği kabul ettikten sonra bunun ilanı ve ahalinin Şiîliğe geçişini sağlamak için ülkenin dört bir yanına elçiler yolladı. Bu elçiler ile emirlerin ilk ulaştığı yerler Bağdat, Isfahan ve Şîâzz şehirleriydi. Bu emir Şîrâz'a ulaştığında ehl-i sünnet mezhebinde büyük bir infial meydana geldi. Şîrâzlılar, Bağdatlıların yaptı̆̆g gibi silahlanarak elçinin bulunduğu camiye Cuma namazı için gittiler. Olası bir hutbe değişikliğine izin vermemek için toplanılmıştı. Olcaytu'nun emri halkın yoğun baskısı nedeniyle değişmeyince Şîrâz ve diğer başkaldıran şehirlerin kadıları derhal görevden azledildi. ${ }^{37}$ Şîrâzlıların Şiîliğe karşı hiç vakit kaybetmeden muhalefet etmeleri şehirdeki Sünnîlerin daha güçlü olduğunu ortaya koyar. Bu sebeple sayısal çoğunluğun Sünnilerden yana ağır bastığını ifade edebiliriz. ${ }^{38}$ Böyle olmakla beraber Şîrâz ve diğer büyük şehirler, Olcaytu'nun emrine karş1 gelmeleri nedeniyle bir yandan direnirken bir yandan da büyük yaptırımlara maruz kaldılar. ${ }^{39}$

35 Şîrâzî, Şî̀âzname, 102-103.

36 Nitekim onun döneminde kelime-i şehadete "Ali Veliyullah" ifadesi eklendiği gibi, sikke ve hutbedeki ifadeler Şiîler lehine değiştirildi. Aynı zamanda Şiîler daha rahat propaganda imkânı buldular. (Manuçehr Murtazavî, Mesâil-i Asr-ı İlhânân, (Tahran: Bünyad-1 Mevkufât, 1385), 224-231.)

37 İbn Battuta, Büyük Dünya Seyahatnamesi, çev. Mümin Çevik, (İstanbul: Üçdal Yayınları, 2000), 153-154. Murtazavî, Mesâil-i Asr-ı İlhânân, 253-256; İbn Battuta'nın eserinde görevden azledilen Şîrâz kadısı Şeyh Mecdeddin İsmail'in Olcaytu tarafından cezalandırılma hadisesi anlatılmıştır. Buna göre; o sırada Karabağ' da bulunan Olcaytu, kadı Mecdeddin'in sarayın köpeklerine parçalatılması emrini verdi. Ancak köpekler kadının önüne gelerek uysal bir şekilde yerde oturup kalınca Olcaytu derhal kadının ayaklarına kapanıp kendisine iltifatta bulundu. Ayrıca ona Şîrâz'da Cimkan bölgesinde yüz köyü bağışladı. (İbn Battuta, Büyük Dünya Seyahatnamesi, 154.)

38 Bkz. 29. dipnot.

39 Şahin, İlhanlılar Döneminde Şiîlik, 184; Osman Gazi Özgüdenli, "Bir Ortaçağ İran Şehrinin Anatomisi: Isfahan (650-1500)", Ortaçağ Türk Iran Araştırmaları Tarihi, (İstanbul: Kaknüs Yayınları, 2006), 454. 
716/1317 yılında babası Olcaytu'nun ölümünden sonra İlhanlı tahtına geçen Ebu Said Bahadır Han döneminde ise onun dini politikasının bir yansıması olarak tasavvuf ehli kişilerin yönetimde ve halk nezdinde itibarları ve yetkeleri artmıştır. Tasavvuf ehli kişilerin Şîrâz'da kişisel servetlerinden ibadetgâhlar inşa ettiği bilinmektedir. Bu bağlamda Şîrâz'da Ebu Abdullah b. Hafif isminde bir mutasavvıf kendi imkânlarıyla yüksek kubbeli bir bina inşa ettirmiştir. 718/1319 yılında Ebu Said Bahadır Han'ın yarlığ gereği bütün Fars topraklarını ve Şîrâz'ın yönetimini Atabek Abiş'in kızı Kerduçin üstlenmiştir. Bununla beraber merkezden müşterek yönetici gönderme âdeti gereği 719/1320 y1lında baskak olarak Emir Toğa vazifelendirilmiştir. Şîrâzname müellifinin belirttiğine göre Şîrâz'da adil bir yönetim örneği sergileyen Emir Toğa, aynı zamanda inşa ettirdiği birçok imaret ile şehir mimari hayatına katkı sağlamıştır. Şîrâz'da Beyza kapıs1 yakınlarında yaptırdığ meyve bahçesi o dönem için oldukça popüler idi. Emir Toğa'dan sonra Şîrâz'da yönetimi bir müddet oğlu Emir Setti baskak vazifesiyle devam ettirdi. Ardından ise bu görevi, Kerduçin (كردوجين)'in kız kardeşi Sultan Hatun'un kocası Kara Mahmut üstlendi. ${ }^{40}$

Daha önce Şîrâz'da yönetimi üstlenmiş olan Kerduçin'in 730/1330 yılında bu defa İlhanlı ailesinden Ebu Said Han'ın kız kardeşi Sâtî Bîk ile beraber aynı vazifeyi elde ettiklerini görmekteyiz. Bu bağlamda Kerduçin'in ve Sâtî Bîk'in Şîrâz'daki vergi gelirlerini ve yönetimi uhdelerine almaları hususunda Ebu Said'in 27 Rebiü'l-evvel 730/18 Ocak 1330'da Yarlıg ${ }^{41}$ hükmü bulunmaktadır. Bu Yarlıg'a göre vergi toplamada görevlilerin zorluk yaşadığı, bazılarının vergilerini vermekten imtina ettiği anlaşılmaktadır. Şîrâz'daki arazilerin önemli bir kısmının İlhanlı ailesinin özel mülkü olduğunu düşünürsek Yarlıg'ta Salgurluların soyundan gelmesine rağmen İlhanlılar ile kan bağı (Mengü Timur'un kızı) bulunan Kerduçin'e İncu gelirlerinin tevcih edilmesi olağan bir uygulama olarak karşımıza çıkar. ${ }^{42}$

40 Ayetî, Tahrir-i Tarih-i Vassaf, 59; Şîrâzî, Şîrâzname, 103.

41 Yarlıg (برليغ) İlhanlıların son dönemlerinde hükümdarın yazılı olarak hükmünü bildiren belgeye verilen isim. (Muin, Ferheng-i Farsî, c. 4, 5256.)

42 Bu Yarlıg şu şekildedir: “... 730 Hani yılına ait vergi gelirleri, süregelen uygulamalar üzere, altun tamga uyarınca, Şehzade-yi Cihan Kerduçin ve Şehzade-yi Cihan Sâtî Bîk'in mürebbilerine havale edilmiştir. Bu zamanda onların naibleri, bazılarının vergilerini ulaştırdı̆̆ını, bir kısmının ise şu ana kadar baki kaldı̆̆ını ve ulaştırmamış olduğunu bildirmişlerdir. Şayet bu şekilde ise, bu suçtur... Hiçbir bahane ver karşı koymaya teşebbüs etmesinler..." (Osman Gazi Özgüdenli, "İlhanlı Hükümdarı Ebu Said Bahadır Han'a Ait Dört Yarlıg" Ortaçağ Türk Iran Araştırmaları Tarihi, (İstanbul: Kaknüs Yayınları, 2006), 270-293.) 


\section{4. Şiraz'da İlhanlı Hâkimiyetinin Sonu İnculuların Güçlenmesi}

Öte yandan Melik İzzeddin 725/1325 yılı Zilkâde ayının son günlerinden Tebriz'de huzurdayken Hace Çoban'ın teşviki ve kışkırtmasıyla öldürüldü. Böylece Melik Cemaleddin ile başlayan süreç son buldu. Zira onun bakiyeleri bir araya gelmek yerine her biri ayrı ayrı istiklâllerini ilan ederek dağıldılar. Bundan sonra Şîrâz'da tarihe İnculular dönemi olarak geçecek olan süreç başladı. ${ }^{43}$ Şeyh Cemaleddin ve onun bakiyelerinin Şîrâz'da varliklarını devam ettirmelerine paralel olarak İnculular 702/1303 yılından itibaren Şîrâz'da İlhanlı egemenliğinde söz sahibi olmaya başlamıştı. Şehirde zaman içinde yaşanan iktidar çekişmesi yerel bazda yeni bir idari mekanizmayı zorunlu kılmaya başladı. Bu sebeple $725 / 1325$ 'den itibaren bağımsız politika gütmeye başlayan İnculular, ortaya çıkan otorite boşluğunu pek te zorlanmadan doldurdular. Zira İlhanlı merkezi otoritesi muhtelif sebeplerle işlevselliğini kaybetmeye başlamıştı.

Bu arada İlhanlıların son dönemlerine yakın bütün İlhanlı ülkesinden toplanan vergi gelirlerinde Şîrâz, büyüklük bakımından üçüncü sırada yer almaktayd $1{ }^{44} \mathrm{Bu}$ sebeple İlhanlı maliyesinin kayda değer kaynaklarının başında gelen Şîrâz'ın merkezi otorite nezdinde ehemmiyetinin ne denli yüksek olduğunu ifade edebiliriz.

Daha önce Fars yönetimini uhdesine almış olan Emir Şerefüddin Mahmud Şah İncu, 734/1334'de Ebu Said döneminde buna ilaveten Kirman, Bahreyn, Kiş ve Isfahan'1 tasarrufu altına aldı. Bunun üzerine Ebu Said Bahadır Han, isyancı İnculuları cezalandırmak için harekete geçti. Asiler cezalandırıldı ve ölüm emirleri verildi. Mahmud Şah'ın kardeşi Emir Gıyaseddin, Ebu Said nezdinde girişimde bulunarak isyan eden İnculuların tamamının Tebarek kalesine hapsedilmesini sağladı. Böylece Şîrâz ve Fars'ın yönetimi İnculularda kalmaya devam etti. ${ }^{45}$

735/1335 yılında Musafir Bey, Ebu Said Bahadır Han'dan aldığ Yarlıg hükmünce Şîrâz'a yönetici olarak atandı. Bu sırada şehrin hâkimi İncululardan Emir Giyaseddin Keyhüsrev idi. Musafir Bey, Şîrâz'a gelmeden önce vekilini göndermişti. Burada amaç muhtemelen olası bir muhalif du-

43 Şîrâzî, Şîrâzname, 100-101.

44 Özgüdenli, ” Bir Ortaçağ İran Şehrinin Anatomisi: Isfahan (650-1500)”, 473.

45 Pîrniya ve Aştiyanî, Tarih-i İran ez Âğaz ta İnkıraz-ı Silsile-i Kacariyye, 540-541. 
rumu önceden öğrenmek ve gereken tedbirleri almak ile alakalıdır. Emir Giyaseddin, güçlü ve istikrarlı bir yönetime sahip olduğu için vekile herhangi bir müdahalede bulunmadı. Bununla beraber bir süre sonra Musafir Bey, Şîrâz'a geldi. Ancak 735 Rebiü'l-ahir ayında Ebu Said Bahadır Han'ın ölüm haberi Şîrâz'a ulaşınca elindeki Yarlıg'ın geçerlilik hükmü kalmadi. ${ }^{46}$

Atabek Ebubekir'in 1260'da ölümünden 1343'de Şeyh Ebu İshak İncu'nun yönetimi üstlendiği dönem arasında kalan süreçte Şîrâz genellikle çalkantılı ve anarşinin hâkim olduğu bir evre yaşadı. Çok kısa bir süre güvenlikli ve sakin bir dönem geçirebildi. Böyle olmasının ana sebebi Moğolların uyguladığı politikalar ve imtiyazlı toprak sahiplerinin halktan topladığı ağır vergilerle meydana getirdiği yönetim anlayışıdır. ${ }^{47}$

İlhanlılar, Şîrâz' da 725/1325'den 735/1335 yılına kadar zayıf da olsa Ebu Said Bahadır Han döneminde yönetici atamak yoluyla hâkimiyet kurulmaya çalıştı. Ancak bu konuda İlhanlılar lehine bir başarı söz konusu olmadı. Bu hanedan, Şîrâz'da 758/1357 yılına kadar varlığını sürdürmeyi başardı. ${ }^{48}$

\section{Sonuç}

Moğolların Yakın Doğu ve Ön Asya'yı kasıp kavuran aynı zamanda baş döndürücü bir hızda ilerleyen istila hareketinin yıkıcılığından itaat ederek kurtulmayı başaran Şîrâz şehri, bu sayede birçok ilim, fikir ve düşünce adamının sığınağı oldu. Belki de Moğol yönetimi döneminde Şîrâz'ın en büyük kazanımı istilaya uğramadığ için ilim ve kültür merkezi olmasıdır. Onların varlığı birçok müessesenin yapımı için itici bir güç vasfı olmuştur. Zincirleme yaşanan bu durum Şîrâz'ın siyasi olmasa da ilmî ve kültürel anlamda zirve dönemlerinde birini yaşamasını sağlamıştır.

Geniş bir sahada hâkimiyet kuran Moğollar, merkezden uzak olan yerlerde tam olarak egemen olamiyor, zaman zaman isyan eden yerel idarecilere karşı merkezden ordu göndermek suretiyle müdahalede bulunuyordu. $\mathrm{Bu}$ bağlamda gevşek bir idari yapılanma ortaya çıkmaktaydı. Bununla beraber

46 Şîrâzî, Şîrâzname, 104.

47 Limbert, Shiraz in the Age of Hafez, 23.

48 Rıza Kurtuluş, “İnculular”, Türkiye Diyanet Vakfi İslam Ansiklopedisi, c. 22, (Ankara: TDV Yay., 2000), 280. 
Moğollar/İlhanlılar, Şîrâz'da yerel idarecilerin yanında Şahne, Râhdârân ve malî işler sorumlusu vergi memurları görevlendirmiş olmasına rağmen sağlam bir otorite kuramamıştır. Hatta birden fazla Şahne'nin bile görev yaptığı bilinmektedir. Bu durumun birincil sebebi kanaatimizce Şîrâz'ın merkezden uzak olmasıdır. Zira merkezden uzak olan yerlerde dönemin şartları gereği askeri ve idari iletişim istikrarlı seyretmez. Yerel idareciler sürekli merkezi otoritenin zaaflarından istifade etmek ister. Bu bağlamda asi duruma düşen yerel idareciler ya şahne ya da merkezden gönderilen ordu vasıtasıyla tedip edilir. Başka bir sebep, Moğolların Şîrâz'ı İncu arazisi olarak tasarruf etmesidir. Yani Mukataa (kiraya verme) usulüne tabi tutulmasıdır. Bu sebeple toprağı işletenlerin yerel halk üzerinde toprak ağalığı sistemini dayatması durumu ortaya çıkmıştır. Uzun süre aynı aileye mensup kişilerin Şîrâz'da toprağa hâkim olması belli bir güce ulaşmalarına imkân sağlamıştır. Bir başkası ise İlhanlı tahtında yaşanan taht değişiklerinin ortaya çıkardığı otorite boşluğunun merkezden uzak yerlerde bağımsızlık içgüdüsünü kuvvetlendirmesidir. Bu bağlamda Gazan Han ile Baydu arasında yaşanan taht mücadelesi örnek verilebilir.

Öte yandan İlhanlı merkezi yönetimi Şîrâz'ı kime 1kta ederse etsin mutlaka bir baskak ve/veya şahne bulundurarak yerel idareciler ile beraber müşterek bir idareci bulunduruyorlard1. Bu durum ister istemez iki taraf arasında çatışmaya zemin hazırlıyordu. Melik İzzeddin ve Emir Âştû arasında yaşananlar sadece bir örnek olarak zikredilebilir. Sonuç olarak bu saydığımız sebepler bağlamında Şîrâz'da istikralı bir İlhanlı idaresi kurulamamıştır.

Son olarak belirtmek gerekirse; 1286-1335 yılları arasında Şîrâz'da İlhan11 hâkimiyetini üç döneme taksim edebiliriz. Birincisi; 1286-1293 yılları arası Salgurlu bakiyelerinin kısa sürelerde değiştiği ve İlhanlı şahnesi ile müştereken Şîrâz'1 yönettikleri dönemdir. İkinci dönem; 1293-1325 yılları arasında Melikü'l-İslam Cemaleddin ve onun oğlu İbrahim'in İncu arazilerinin geliri karşılığında Şîrâz'da bir nevi dihkan mevkiinde olduğu dönemdir. Bu arada ikinci ve üçüncü dönem arasında (1319-1330) Şîrâz'da İlhanlı soyundan gelme Salgurlu bakiyeleri ile bizzat İlhanlı hükümdarlarının birinci derece akrabaları İncu gelirlerinde pay sahibi olmuştur. Ancak kısa sürelerde bu pay sahipleri değişkenlik göstermiştir. Üçüncü dönem; 1325-1335 yılları arasında İlhanlı merkezi otoritesinin zayıflamasına paralel olarak Şîrâz'ın İnculular tarafından büyük oranda bağımsız yönetildiği dönemdir. Şîrâz'da İlhanlı hâkimiyetinin her dönemde bir öncekinden 
daha fazla zayıfladığını ve nihayetinde kaybedildiğini belirtmek gerekir. Ayrıca bu üç dönemde de merkezden yönetici atanarak şehirdeki İlhanlı nüfuzu korunmaya çalışılmıştır. Bu durum ilk dönem için oldukça yoğun iken sonrasında giderek etkisini yitirmiştir. Hatta İnculular döneminde iyiden iyiye sembolik bir hal almıştır.

\section{Kaynakça}

Ayetî, Abdü'l-Muhammed. Tahrir-i Tarih-i Vassaf, Tahran: İntişarat-1 Bünyad-1 Ferheng-i İran, 1346hş.

Beyânî, Şîîn. Din-u Devlet Der Iran Ahd-ı Moğol, c. 2, Tahran: Merkez-i Neşr-i Danişgahi, 1371hş.

Bosworth, C. E. Doğuşundan Günümüze İslam Devletleri Tarihi, çev. Hande Canlı. İstanbul: Kaknüs Yayınları, 2005.

Efser, Kerametullah. Tarih-i Baft-ı Kadim-i Şîrâz, Tahran: İntişarat-1 Encomin-i Asar ve Mefahir-i Ferhengi, 1374hş.

El-Cûzcânî, Minhâc-1 Sirâc. Tabakât-ı Nâsırî, çev. Erkan Göksu. Tokat: Taşhan Kitap Yayınları, 2011.

El-Kâşânî, Ebu'l-Kasım Abdullah b. Muhammed. Tarih-i Olcaytu, Tahran: İntişarat-1 İlmi ve Ferhengî, 1384hş.

Fazlullah, Reşîdüddin. Câmiu't-Tevârih -ilhanlılar Kısmı-, çev. İsmail Aka, Mehmet Ersan, Ahmad Hesamipour Khelejani. Ankara: TTK Yayınları, 2013.

İbn Battuta, Büyük Dünya Seyahatnamesi, çev. Mümin Çevik, İstanbul: Üçdal Yayınları, 2000.

İbnü'l-Esir, el-Kâmil fi 't-Tarih Tercümesi, c. 10, çev. Ahmet Ağırakça vd., İstanbul: Hikmet Neşriyat, 2008.

Kurtuluş, Rıza. "İnculular", Türkiye Diyanet Vakfı İslam Ansiklopedisi, 22: 280-281. Ankara: TDV Yayınları, 2000.

Limbert, John. Shiraz in the Age of Hafez, Seattle \& London: Universty of Washington Press, 2004.

Merçil, Erdoğan, "Salgurlular", Türkiye Diyanet Vakfi İslam Ansiklopedisi, 36: 29-31. Ankara: TDV Yayınları, 2009. 
Merçil, Erdoğan. Salgurlular, Ankara: TTK Yayınları, 1991.

Muin, Muhammed. Ferheng-i Farsî, c. 1-4, Tahran: Müessese-i İntişarat-i Emir Kebir, 1388.

Murtazavî, Manuçehr. Mesâil-i Asr-ı İlhânân, Tahran: Bünyad-ı Mevkufât, 1385 hş.

Müstevfî, Hamdullah. Nüzhetü'l-Kulub, çev. Guy Le Strange. Leiden 1919.

Özgüdenli, Osman Gazi. “İhanlı Hükümdarı Ebu Said Bahadır Han'a Ait Dört Yarlı"” Ortaçağ Türk Iran Araştırmaları Tarihi, İstanbul: Kaknüs Yayınları, 2006.

Özgüdenli, Osman Gazi. "İncu”, Türkiye Diyanet Vakfi İslam Ansiklopedisi, 22: 281. İstanbul: TDV Yayınlar1, 2000.

Özgüdenli, Osman Gazi. "Şîrâz”, Türkiye Diyanet Vakfi İslam Ansiklopedisi, 36: 182-184. İstanbul: TDV Yayınlar1, 2010.

Özgüdenli, Osman Gazi. Gazan Han ve Reformlarl, İstanbul: Kaknüs Yayınları, 2009.

Özgüdenli, Osman Gazi.” Bir Ortaçağ İran Şehrinin Anatomisi: Isfahan (650-1500)", Ortaçă̆ Türk İran Araştırmaları Tarihi, Kaknüs Yayınları, İstanbul 2006.

Petrushevsky, I. P. “The Socio-Economic Condition of İran Under The İlkhans", The Cambridge History of Iran, 5: 483-537. Cambridge University Press, 1968.

Pîrniya, Hasan ve Aştiyanî, Abbas İkbal. Tarih-i İan ez Â̆gaz ta İnkıraz-ı Silsile-i Kacariyye, Tahran: Neşriyat-1 Heyyam, 1380hş.

Spuler, Bertold. İran Moğolları, çev. Cemal Köprülü. Ankara: TTK Yayınlar1, 2011.

Şahin, Hanifi. İlhanlılar Döneminde Şiîlik, İstanbul: Ötüken Yayınları, 2010.

Şirazî, Zerkûb. Şîrâzname, tsh. İsmail Vaiz Cevadî. Tahran: İntişarat-1 Bünyad-1 Ferheng-i İran, 1350hş.

Üçok, Bahriye. İslam Devletlerinde Türk Naibeler ve Kadın Hükümdarlar, İstanbul, Bilge Kültür Sanat Yayınları, 2011. 
